\title{
The Role of 21st century Learner Skills of Physical Education and Sports Teachers and Teacher Candidates on Teacher Skills
}

\author{
Zehra CERTEL ${ }^{1}$, Ziya BAHADIR ${ }^{2}$,Ramazan TOPUZ ${ }^{3}$
}

1Akdeniz University, Faculty of Sport Sciences - Antalya- Turkey, zcertel@akdeniz.edu.tr 2Erciyes University, Faculty of Sport Sciences, Kayseri, Turkey, ziyabahadir40@hotmail.com 3Selçuk University, Faculty of Sport Sciences, Konya, Turkey,ramazan_topuzz@hotmail.com Address Correspondence to Z, Bahadır, e-mail: ziyabahadir40@hotmail.com

$A$

\begin{abstract}
In this study, the comparison of 21st century learner and teacher skills of physical education and sports teachers and teacher candidates and the role of 21st century learner skills on 21st century teacher skills were examined. Research is in relational scanning model. The sample of the study consists of 171 physical education and sports teachers working in Kayseri province and 184 students who are physical education and sports education students of Erciyes University Faculty of Sport Sciences. The sample consisted of 171 physical education teachers and 184 teacher candidate (total $\mathrm{N}=355$ ) selected by random sampling method from the universe. In this research, 21st learner skills use scale developed by Göksün (2016) and 21st century teacher skills use scale developed by Göksün (2016) were used as the data collection tool. T-test and multiple regression analysis were used for data analysis. According to the findings, there was no significant differences in 21st century learner skills of teacher and teacher candidates, but significant differences were found in 21st century teacher skills. While the 21st century teachers' skills are predicted by innovative, cooperation and flexibility skills, the prospective teachers are predicted by cognitive skills.
\end{abstract}

Key words: 21st century learner skills, 21st century teacher skills, physical education and sports teacher and candidate.

\section{INTRODUCTION}

The rapid change of social, cultural, economic and technological developments in our age increases the importance of high level cognitive skills of individuals such as being able to develop high level of cooperation, effective communication, recognition of different cultures and thinking focused on solving problems. For many young people, schools are the only place where these competences and skills can be learned. In order to adapt to 21st century educational conditions and improve learning processes, it is only possible with teachers who know the learner skills well and can guide the teaching processes in line with these skills" $(12,14)$.

When the body of literatüre is examined "21st century learner skills were first expressed by Turkish Industrialists' Businessmen's Association (31). Theoretical structure has been gained in the body of literature by The Organization for Economic Development and Cooperation (OECD), the
American School Librarians Society, (AASL standards) Trilling and Fadel (30) and Wagner (32)".

OECD New Millennium Learners: The OECD tackles 21st century skill competences in three dimensions: information, communication and ethical and social impact. Information size: includes two sub-dimensions, information as source and information as product. Information as a source is defined as finding information in a fast and effective way, organizing, evaluating the suitability for the work and storing it in digital environment for reuse. Skills related to this sub-dimension are information literacy, research, inquiry and media literacy. Knowledge as a product is defined as analyzing, interpreting, restructuring, producing new information and their skills are listed as creativity, innovation, problem solving and decision making (3). The communication dimension, which includes the sub-dimensions of effective communication and collaboration and virtual interaction, includes the 
use of adequate available tools, the use of the right language, participation in digital culture, the ability of young people to use fluent and daily basic practices, and the ability to interact of friend and interest groups in virtual groups. Collaboration / teamwork and flexibility and compliance, critical thinking and communication are defined as skills of this sub-dimension. The ethical and social impact dimension are the third dimension includes social responsibility and social impact sub-dimensions. The social, cultural and economic effects of these concepts should be taken into consideration and it is thought that they have an impact on youth and youth have effects on actions (3).

AASL Standards: Areas within the framework of AASL standards; "1) research, critical thinking and information acquisition, 2) determining results, making decisions, adapting information to new situations and creating new information, 3) participation and sharing knowledge in an ethical and productive manner as part of a democratic society, 4) personal and aesthetic development "(1, 10). When the standards offered by AASL are examined, the necessity of verging individual skills such as creating new knowledge, productive participation and innovation emerges.

Trilling and Fadel (30): In their work, They sort 21 yy. skills as. "learning and innovation skills (learning to renew and learn)", "digital literacy skills (information media and information and communication technologies literacy)" and "career and life skills (readiness for professional life and attention to personal development)". Wagner (32): has classify 21st century skills under seven headings in terms of learners. He defined these skills as surviver skills". According to Wagner (32) the skills that 21st century learners should have are "1) critical thinking and problem solving, 2) systems and interpersonal collaboration and leadership, 3) quick intelligence and adaptation, 4) entrepreneurship and taking, initiative 5) effective oral and written communication, 6) access to and analysis of information, 7) curiosity and imagination.

When the theoretical structure of 21st century learner skills is examined, it is seen that it consists of similar skills and competences. In addition to defining these skills, it is important to focus on how they should be taught. The discussions advocate that skills and competences should be taught in the content of the courses as integrated into the curriculum, not as separate subjects. In particular, the importance of developing and evaluating general skills and competences that help the child to transfer learning to other curriculum areas, future learning situations and life experiences is emphasized (3). Sanders and Rivers (25) alleged that the effective desing of the teaching process by a teacher who plays a key role in the teaching process can increases students' motivation to learn and improve performance, and $90 \%$ of learning can be provided, otherwise only $37 \%$ will be provided.

Teacher training systems are undergoing a transformation towards the understanding of technopedagogical content knowledge (TPACK). TPACK is a model that emerges from the interaction of three components based on technology, pedagogy and content knowledge (20). In this model, it a teacher's pedagogical approaches that he applies when presenting the content in the curriculum are stated as the acquisition of the curriculum by using technology effectively in these processes while making for work (12). However, it is seen that the facilities of the school are very important for this.

In our country, in 2018, MoNE (Ministery of National Education) teachers' general professional competencies were revised with a large scale participation (21). In the update, "field knowledge and field education knowledge competencies were added to the general competencies, so that a holistic and single text was created to cover the competences of each teacher in his / her own field". The general competencies of the teaching profession, which are updated in this context, are composed of three related and complementary competency areas, namely professional knowledge, professional skills and attitudes and values, and 11 competencies and 65 indicators related to these competences below them" (21).

The special field competencies of the physical education teachers who form the sample of the research are composed of six competency fields that are "a) planning and organizing the teaching process, b) ensuring and preserving the development of physical performance c) celebrating national holidays in accordance with their meaning and importance, d) monitoring and evaluating development performance, e) cooperation with the societyand school, f) professional development" and the 28 indicators below them (22). Melvin (15) emphasizes the necessity of the evaluation of that in what scales teachers use the skills identified in the criteria listed in the teaching activities. Only then,he 
states that it can be reached to the judgement that there is an effective teacher.

As a result, it seems possible to say that learner skills and teacher skills are processes that affect each other.

When the body of literature is examined, there are studies on 21st century learner and teacher skills $(7,8,9,18,24,26,29,33,34,36)$. Göksün (10) did a doctoral dissertation on the 21st century on learner and teacher skills in education faculties.. However, there is no study on physical education and sports lesson teachers and candidates who are different from other courses. In this context, the comprasion of the levels of having 21st century learner and teacher skills of both the teachers and the prospective teachers and the revealing of the role of 21st century learner skills on 21st century tecaher skills are the aims of the study. It is thought to contribute to the body of literature.

\section{METHOD}

The research is in scanning model. The universe of the study consists of 580 physical education teachers working in secondary and high schools in Kayseri and 283 teacher candidates studying in Physical Education and Sports Education Department of Erciyes University Faculty of Sport Sciences. The sample consisted of 171 physical education teachers and 184 teacher candidate (total $\mathrm{N}=355$ ) selected by random sampling method from the universe. The mean age of teachers was $36.05 \pm$ 7.38 years and their professional seniorities were $11.01 \pm 6.82$ years. $55.9 \%(n=95)$ of the teachers work in secondary school and $44.1 \%(n=75)$ in high school. The mean age of the students was $21.51 \pm$ 2.29 years and their academic achievement averages were $2.89 \pm .39 .26 .2 \%(\mathrm{n}=45)$ of the students study in the second class, $44.2 \%(\mathrm{n}=76)$ in the third class and $29.7 \%(n=51)$ in the fourth class.

\section{Data Collection Tool}

In the research, "21st century learner skills use scale and 21st century teacher skills use scale developed by Göksün (2016)" were used.

\section{1st Century Learner Skills Scale}

The scale was developed in Göksün (10) 's doctoral thesis. "Exploratory factor analysis (EFA) and confirmatory factor analysis (CFA) were conducted in order to conduct validity and reliability analyzes of the data collection tool " (10). 21st century. learner skills scale consists of 31 items and is in the form of a five-point likert. The scale has four sub-dimensions, cognitive (item number $=17, \alpha$ $=.877$ ), collaboration and flexibility (item number $=$ $6, \alpha=.672$ ), autonomous (item number $=6 ; \alpha=.706$ ) innovativeness (item number $=2 ; \alpha=.818$ ) skills. In this study, internal consistency coefficients were found to be $\alpha=.90$ in cognitive sub-dimension, collaboration and flexibility $\alpha=.66$, autonomous $\alpha=$ .70 innovativeness $\alpha=80$ and in the total scale $\alpha=$ .92.

\section{1st Century Teacher Skills Scale}

The scale was developed by Göksün (10). Exploratory factor analysis (EFA) and confirmatory factor analysis (CFA) were conducted to the scale. 21 st century the teacher skills scale consists of 27 items and is in the form of a five-point likert. The scale has five sub-dimensions, administrative skills (item number $=12, \alpha=.852$ ), technopedagogical skills (item number $=8, \alpha=.629$ ), affirmative skills (item number $=3 ; \alpha=.419$ ) flexible teaching skills (item number $=2 \alpha=.752$ ), generative skills (item number $=2 ; \alpha=.714)$. In this research, it was found that in the sub-demiensions, administrative $\alpha=.87$, affirmative $\alpha=.73$, generative $\alpha=.81$ flexible teaching $\alpha=.80$, technopedagogical $\alpha=.77$ and in the total scale $\alpha=.92$.

\section{Statistical analysis}

In the research, in the analysis of the data, in addition to descriptive statistical methods, Kolmogorow Smirnow test was used to determine whether the data showed normal distribution. The test results indicate that the data is not normally distributed. At this stage, kurtosis and skewness coefficients were examined to check whether the data provided other normality assumptions. The kurtosis and skewness coefficients of the data were found to be between +1.5 and -1.5 . This is interpreted as the scores obtained from the study showed a normal distribution (28). For this reason, t-test, Pearson Moments Multiplication Correlation and multiple regression analysis tests were used for data analysis. The results were evaluated at 0.05 significance level. 


\section{FINDINGS}

In this section, findings related to the data of teacher and prospective teachers are given.

\begin{tabular}{|c|c|c|c|c|c|c|c|}
\hline Scale & Who & & $\mathbf{N}$ & $\overline{\mathrm{X}}$ & Ss & $t$ & p \\
\hline \multirow{2}{*}{ Cognitive Skills } & Teacher & Candidates & 184 & 4.09 & .58 & & \\
\hline & Teachers & & 171 & 4.17 & .37 & -1.506 & .133 \\
\hline \multirow[t]{2}{*}{ Innovativeness Skills } & Teacher & Candidates & 184 & 3.91 & .89 & & \\
\hline & Teachers & & 171 & 4.06 & .56 & -1.954 & .052 \\
\hline \multirow[t]{2}{*}{ Collaboration and Flexibility Skills } & Teacher & Candidates & 184 & 3.75 & .68 & & \\
\hline & Teachers & & 171 & 3.74 & .53 & .274 & .784 \\
\hline \multirow[t]{2}{*}{ Autonomous Skills } & Teacher & Candidates & 184 & 3.77 & .66 & & \\
\hline & Teachers & & 171 & 3.69 & .57 & 1.100 & .272 \\
\hline \multirow[t]{2}{*}{ Total Scale } & Teacher & Candidates & 184 & 3.88 & .57 & & \\
\hline & Teachers & & 171 & 3.92 & .37 & -.700 & .484 \\
\hline
\end{tabular}

When Table 1 is examined, it is observed that teachers and teacher candidates use the highest level of cognitive skills $(X$ teacher $=4.17 ; X$ teacher candidate $=4.09)$. The subscales of 21st century learner skills. Cognitive skills $(\mathrm{t}=-1.506, \mathrm{p}=.133$; $\mathrm{p}>$
.05), innovativeness skills $(\mathrm{t}=-1.954, \mathrm{p}=.052 ; \mathrm{p}>.05)$, collaboration and flexibility skills, $(\mathrm{t}=.274, \mathrm{p}=.784$; $\mathrm{p}>.05)$, autonomous skills $(\mathrm{t}=-1.506, \mathrm{p}=.133 ; \mathrm{p}>.05)$ and the total scale $(\mathrm{t}=-$. 700, $\mathrm{p}=.484 ; \mathrm{p}>.05)$ no statistically significant difference was found.

\begin{tabular}{|c|c|c|c|c|c|c|c|}
\hline Scale & Who & & $\mathbf{N}$ & $\bar{X}$ & Ss & $\mathbf{t}$ & $\mathrm{p}$ \\
\hline \multirow[t]{2}{*}{ Administrative skills } & Teacher & Candidates & 184 & 4.05 & .58 & & \\
\hline & Teachers & & 171 & 3.89 & .63 & $2.547^{*}$ & .011 \\
\hline \multirow[t]{2}{*}{ Technopedagogical Skills } & Teacher & Candidates & 184 & 3.74 & .89 & & \\
\hline & Teachers & & 171 & 3.51 & .56 & $3.487^{*}$ & .001 \\
\hline \multirow[t]{2}{*}{ Affirmative Skills } & Teacher & Candidates & 184 & 4.49 & .68 & & \\
\hline & Teachers & & 171 & 4.38 & .53 & 1.707 & .089 \\
\hline \multirow[t]{2}{*}{ Generative Skills } & Teacher & Candidates & 184 & 3.79 & .66 & & \\
\hline & Teachers & & 171 & 3.55 & .57 & $2.036^{*}$ & .043 \\
\hline \multirow[t]{2}{*}{ Flexible Teaching Skills } & Teacher & Candidates & 184 & 3.68 & .96 & & \\
\hline & Teachers & & 171 & 3.69 & .95 & -.077 & .939 \\
\hline \multirow[t]{2}{*}{ Total Scale } & Teacher & Candidates & 184 & 3.95 & .57 & & \\
\hline & Teachers & & 171 & 3.80 & .37 & $2.336^{*}$ & .020 \\
\hline
\end{tabular}

${ }^{*} \mathrm{p}<.05$

When Table 2 is examined, it is seen that teachers and teacher candidates use the highest level of affirmative skills (X-teacher $=4.38$; X-teacher candiate $=4.49)$. Statistically significant differences were found between the subscales of 21st century teacher skills, administrative skills $(\mathrm{t}=2.547, \mathrm{p}=$ $.011 ; \mathrm{p}<.05)$, technopedagogical skills $(\mathrm{t}=3.487, \mathrm{p}=$ $.001 ; \mathrm{p}<.05)$, generative skills $(\mathrm{t}=2.036, \mathrm{p}=.043 ; \mathrm{p}$ $<.05)$ and in the total scale $(t=2.336, p=.020 ; \mathrm{p}<05)$. Pre-service teachers have high average scores in the given skills. On the other hand, there were no significant differences in affirmative $(t=1.707, p=$ $.089 ; \mathrm{p}>.05)$ and flexible teaching skills $(\mathrm{t}=-.077, \mathrm{p}=$ $.939 ; \mathrm{p}>.05)$.

In accordance with the objectives of the study, firstly, Pearson Moments Multiplication Correlation technique was used to reveal the relationship between the use of $21^{\text {st }}$ century learner skills and the use of 21st century teacher skills of teachers and prospective teachers. In the table below, the correlation relationships between the variables of the teachers are given. 
Table 3. Correlation relationships between the variables related to the predictions of 21st century teaching skills of teacher candidates in Physical Education and Sports Teachers (N=171)

\begin{tabular}{lllll}
\hline & Cognitive & Innovativeness & $\begin{array}{l}\text { Collaboration and } \\
\text { Flexibility }\end{array}$ & Autonomous \\
\hline 21st Century Teacher Skills & $.348^{* *}$ & $.469^{* *}$ & $.430^{* *}$ & $.174^{*}$ \\
& .000 & .000 & .000 & .000 \\
\hline
\end{tabular}

${ }^{*} \mathrm{p}<.05, * * \mathrm{p}<.01$

As seen in Table 3, significant relationships results regarding the prediction of 21st century were found to be positively between the subteachers skills according to the cognitive, dimensions of 21st century teacher skills and 21st innovativeness, collaboration and flexibility skills century learner skills, cognitive skills $(r=.348, \mathrm{p}=$ variables of physical education teachers' 21st $.000)$, innovativeness $(\mathrm{r}=.469, \mathrm{p}=.000)$, century learner skill use sub-dimensions are given in collaboration and flexibility skills $\mathrm{r}=.430, \mathrm{p}=.000), \quad$ Table 4 .

autonomous skills $(\mathrm{r}=.174, \mathrm{p}=.000)$. The regression

\begin{tabular}{llllll}
\hline \multicolumn{5}{l}{ Table 4. Results of Multiple Regression Analysis of Prediction of 21st Century Teacher Skills of Teachers' } \\
\hline Variables & $\mathbf{B}$ & Std.Error & Beta & $\mathbf{t}$ & $\mathbf{p}$ \\
\hline Constant & .554 & .484 & & 1.145 & .254 \\
\hline Cognitive skills & .093 & .149 & .055 & .626 & .532 \\
\hline Innovativeness Skills & .401 & .079 & .358 & $5.044^{*}$ & .000 \\
\hline Collaboration and Flexibility & .353 & .100 & .296 & $3.525^{*}$ & .000 \\
\hline Autonomous Skills & -.023 & .088 & -.021 & -.265 & .792 \\
\hline $\mathrm{R}=.557, \quad \mathrm{R} 2=.311 \quad \mathrm{~F}(4,166)=18.692$, & $\mathrm{p}=.000$. & & & & \\
\hline${ }^{*} \mathrm{p}<.05 ;{ }^{* *} \mathrm{p}<.01$ & & & & & \\
\hline
\end{tabular}

As it can be seen in Table 4, the sub-scales of 21 st century learner skills in the teacher study group predict 21st century teacher skills at significant level $[\mathrm{F}(4,166)=18.692, \mathrm{p}<.000]$. In the regression analysis, it was determined that all the predictive variables explained $31 \%$ of the total variance of 21st century teacher skills scores. When t-test results related to the significance of regression coefficients were examined, innovativeness $(\mathrm{t}=$
5.044, $\mathrm{p}=.000 ; \mathrm{p}<.05)$ and collaboration and flexibility $(\mathrm{t}=3.525, \mathrm{p}=.000 ; \mathrm{p}<.05)$ skills subscales were significant predictors subscales and other subscales were not significant predictors $(p>.05)$. Correlation relationships between the variables related to the predictions of 21st century teaching skills (Table 5) and Multiple Regression Analysis Results are given in (Table 6).

Table 5. Correlation relationships between the variables related to the predictions of 21st century teaching skills of teacher candidates $(\mathrm{N}=184)$

\begin{tabular}{lcccc}
\hline & Cognitive & Innovativeness & Collaboration and Flexibility & Autonomous \\
\hline 21st Century Teacher & $.676^{* *}$ & $.410^{* *}$ & $.520^{* *}$ & $.464^{* *}$ \\
Skills & .000 & .000 & .000 & .000 \\
& & & & \\
\hline${ }^{* *} \mathrm{p}<.01$ & & & \\
\hline
\end{tabular}

As seen in Table 5, significant relationships were positively found between the sub-dimensions of 21st century teacher skills and 21st century learner skills of the students, cognitive skills $(\mathrm{r}=$
$.676, \mathrm{p}=.000)$, innovativeness $(\mathrm{r}=.410, \mathrm{p}=.000)$, collaboration and flexibility skills $(\mathrm{r}=.420, \mathrm{p}=.000)$, autonomous skills $(\mathrm{r}=.465, \mathrm{p}=.000)$. 
Table 6. Results of Multiple Regression Analysis of Prediction of 21st Century Teacher Skills of Teacher candidates'

\begin{tabular}{|c|c|c|c|c|c|}
\hline Variables & B & Std. Error & Beta & $t$ & $p$ \\
\hline Constant & 1.225 & .220 & & 5.577 & .000 \\
\hline Cognitive skills & .519 & .075 & .550 & $6.941^{*}$ & .000 \\
\hline İnnovativeness Skills & .040 & .040 & .065 & .998 & .320 \\
\hline Collaboration and Flexibility & .085 & .064 & .105 & 1.331 & .185 \\
\hline Autonomous Skills & .034 & .060 & .041 & .556 & .579 \\
\hline
\end{tabular}

$\begin{array}{lll}\mathrm{R}=.687, & \mathrm{R} 2=.472 & \mathrm{~F}(4-179)=40.067, \quad \mathrm{p}=.000\end{array}$

${ }^{*} \mathrm{p}<.05$

As it can be seen in Table 6, in the study

group of teacher candidates, the sub-scales of 21st century learner skills significantly predict 21st century teacher skills $[\mathrm{F}(4,179)=40.067, \mathrm{p}<.000]$. In the regression analysis, it was determined that all the predictive variables explained $47 \%$ of the total

\section{DISCUSSION \& CONCLUSION}

In this study, in addition to the comprasion of the level of having 21st century learner and teacher skills of physical education teachers and candidates and the role of 21st century learner skills on 21st century teacher skills were examined. The mean scores of 21st century learning skills of the teachers and prospective teachers who participated in the study were found to be above the middle level. They use the mostly the cognitive skills from 21st century learner skills. Teachers and candidates use skills to solve real-life problems less, such as autonomous skills, collaboration and flexibility skills. Göksün and Kurt (11). They have reached similar conclusions in the study on teacher candidates studying at universities in different regions of Turkey in various branches. Prospective teachers' 21st century learner skills are above intermediate level and the most commonly used skills are cognitive skills.

Şahin (26) in his study reported that candidate teachers received the highest score in the subdimension of alternative cognitive characteristics. The studies support our research. It can be thought that this is due to the fact that the theoretical courses in physical education teacher training programs are considerable amounts of. Teachers and candidates use their 21st century. skills "above the middle level". It was observed that the most commonly used skills of the teacher candidates were "affirmative skills". This skill "describes the exhibition of correct behaviours by transforming variance of 21st century teacher skills scores. When t-test results related to the significance of regression coefficients were examined, it was found that cognitive skills $(\mathrm{t}=6.941, \mathrm{p}=.000 ; \mathrm{p}<.05)$ were significant predictors and other subscales were not significant predictors $(\mathrm{p}>.05)$.

them into teaching skills of acceptive approaches ". It is thought that teachers and teacher candidates attach importance to reinforcement tendency because of their behavioral approach in the past. The study of Göksun and Kurt (11) support our research. Şahin (26) conducted a study on the levels of having the characteristics of "student of the new millennium of teacher candidates and stated that they had above-average in the skills mentioned. As a result, the fact that physical education teachers and candidates have a high level of teaching skills can provide them easinesses in their professional lives.

There was no significant difference among 21st century learner skills of physical education teachers and candidates who participated in the study. It can be said that teachers and candidates use 21st century learner skills at a similar level.

When the 21st century teacher skills of physical education and sports teachers and candidates were examined, In the total scale, the scores of teacher candidates were higher in administrative, technopedagogical and generative skill subdimensions. It can be said that the candidates use these skills more than the teachers. In the updates of the Turkish education system, in addition to national competency. some standards whose international validty were accepted were included. In this context, it is natural that prospective teachers have higher 21st century teacher skills compared to teachers. In the studies of the body of literature, it was emphasized that teachers and prospective teachers use technopedagogical skills inadequately 
and they must improve them and the reason for that, it is stated that "deficiencies such as instructor, physical facilities and technological infrastructure in the institutions training teachers are effective $(13,16$, 19, 27). In addition, Adıgüzel and Yüksel (2) in their study stated that "in the process of integration of technology into education, serious educational problems arise in terms of teachers, students and the educational environment. Bass (4) stated that most of this problem stems from the fact that "teaching technologies aren't supported with appropriate pedagogical approaches.

In accordance with the objectives of the study, firstly, relationship between the 21st century. teacher skills use and 21st century learner skills use subdimensions of teachers and prospective teachers were revealed. In the study, significant and positive relationships were found at medium level between the 21st century, learner skills sub-dimensions, cognitive, innovativeness, collaboration and flexibility and autonomous skills and the 21st century teacher skills. This result means that 'as the 21st century learner skills use of teachers and prospective teachers increases, the 21st century teacher skills use increases'. This finding can be interpreted as "good teachers are also good students".

Sanders and Rivers (25) state that "learner skills form teacher skills, and teacher skills will improve learner skills". A teacher must use all his/or her skillss in the a face of a group of student who use their learning skills at the highest level. Conversely, a teacher who uses all teaching skills can motivate the student to the lesson and make him participate in lesson.

In the teacher study group, as a result of multiple regression analysis on the prediction of 21st century teacher skills, it was determined that the predictive variables of cognitive, innovativeness, collaboration and flexibility, and autonomous skills explained $31 \%$ of the variance of 21 st century teacher skills and the innovativeness and collaboration and flexibility skill dimensions of 21st century learner skills positively predicted 21st century teacher skills at significant level. The learner skilled teachers who have skills of the ability of using new technologies and have innovativeness and fexibility and cooperation are expected to be 21st century. teachers. Brun and Hinostroza (6) in their study emphasized the need to educate teachers who use new technologies effectively.
In the prospective teacher working group, multiple regression analysis was conducted on the prediction of 21st century teacher skills and it was determined that he predictive variables of cognitive, innovativeness, collaboration and flexibility, and autonomous skills explain $47 \%$ of the variance of 21st century teacher skills and the cognitive skills of the 21st century learner skills positively predict the 21st century. teacher skills at significant level. Billing (5) stated that "cognitive skills can solve many learning problems encountered in educational environments and can be transferred to skills such as cooperation, self-management and selfconfidence. Young' (36) states that the 21st century learners have a generation conflict with their teachers, and this situation leads to cognitive skills work.

As a result, it is necessary to train individuals who are innovative, able to cooperate and who have flexibility skills. In this context, it is clear that teachers who cannot use the technology required by the age and cannot adapt to new developments, technologies and ideas will not have the chance to raise individuals who will be the architects of the future.

\section{REFERENCES}

1. AASL (American Association of School Librarians), Standards for the 21st century learner, 2007. (Akt; Derya Orhan Göksun, 2016)

2. Adıgüzel, A. ve Yüksel, İ. (2012). Öğretmenlerin öğretim teknolojileri entegrasyon becerilerinin değerlendirilmesi: Yeni pedagojik yaklaşımlar için nitel bir gereksinim analizi. Necatibey Eğitim Fakültesi Elektronik Fen ve Matematik Eğitimi Dergisi, 6(1), 265-286.

3. Ananiadou, K. and M. Claro (2009), "21st Century Skills and Competences for New Millennium Learners in OECD Countries", OECD Education Working Papers, No. 41, OECD Publishing. http://dx.doi.org/10.1787/218525261154OECD

4. Bass R., (2000). Technology, evaluation, and the visibility of teaching and learning. New Directions for Teaching and Learning, 83, 47.

5. Billing, D. (2007). Teaching for transfer of core/key skills in higher education: Cognitive skills. Higher education, 53(4), 483-516.

6. Brun, M. ve Hinostroza, J. E. (2014). Learning to become a teacher in the 21st century: ICT integration in initial teacher education in Chile. Journal of Educational Technology \& Society, 17(3), 222-238.

7. Bunker, D. H. (2012). Teachers' orientation to teaching and their perceived readiness for 21st century learners. Yayınlamamış doktora tezi. The University of Texas at Arlington.

8. Çoklar, A.N. (2008). Öğretmen adaylarının eğitim teknolojisi standartları ile ilgili özyeterliklerinin belirlenmesi. 
Yayınlanmamış doktora tezi. Anadolu Üniversitesi, Eğitim Bilimleri Enstitüsü, Eskişehir.

9. Gökçe, E. (2000). Yirmibirinci yüzyılın öğretmeni. Çağdaş Eğitim Dergisi, 270, 21- 26.

10. Göksün, D.O. (2016). Öğretmen adaylarının 21.yy. öğrenen becerileri ve 21. yy. öğreten becerileri arasındaki ilişki. (Yayınlanmamış Doktora Tezi). Anadolu Üniversitesi, Eğitim Bilimleri Enstitüsü, Eskişehir, Türkiye.

11. Göksün, D. O. ve Kurt, A. A. (2017). Öğretmen adaylarının 21. yüzyıl. Öğrenen becerileri kullanımları ve 21. yüzyıl. öğreten becerileri kullanımları arasındaki ilişki. Eğitim ve Bilim, 42(190), 107-130.

12. Harris, J., Mishra, P. ve Koehler, M. (2009). Teachers' technological pedagogical content knowledge and learning activity types: Curriculum-based technology integration reframed. Journal of Research on Technology in Education, 41(4), 393-416.

13. İşigüzel, B. (2014). Almanca öğretmen adaylarının teknopedagojik eğitime yönelik yeterlik düzeylerinin incelenmesi. Journal of International Social Research, 7(34), 768-778.

14. Mazman, S. G. ve Koçak Usluel, Y. (2011). Bilgi ve iletişim teknolojilerinin öğrenme-öğretme süreçlerine entegrasyonu: Modeller ve göstergeler. Eğitim Teknolojisi Kuram ve Uygulama, 1(1), 62-79.

15. Melvin, L. (2011). How to keep good teachers and principals: practical solutions to today's classroom problems. R\&L Education.

16. Karadeniz, Ş. ve Vatanartıran, S. (2015). Primary school teachers' technological pedagogical content knowledge. Elementary Education Online, 14(3), 1017-1028

17. Karagözoğlu, G. (2005). Eğitim Sistemimizde Reform Çalışmalarına Genel Bakış, Yeni İlköğretim Programlarını Değerlendirme Sempozyumunda sunulmuş bildiri, 14-16 Kasım, Kayseri: Erciyes Üniversitesi.

18. Kereluik, K., Mishra, P., Fahnoe, C. ve Terry, L. (2013). What knowledge is of most worth: Teacher knowledge for 21st century learning. Journal of Digital Learning in Teacher Education, 29(4), 127-140.

19. Klopfer, E., Osterweil, S., Groff, J. ve Haas, J. (2009). Using the technology of today in the classroom today: The instructional power of digital games, social networking, simulations and how teachers can leverage them. The Education Arcade, 1-20.

20. Koehler, M. J. ve Mishra, P. (2009). What is technological pedagogical content knowledge?. Contemporary Issues in Technology and Teacher Education, 9(1), 60-70. Akt. Ceylan, 2015)

21. MEB (2018). Öğretmenlik mesleği genel yeterlikleri MEB yayınları.

22. MEB (2018a). Beden Eğitimi öğretmeni Özel Alan yeterlikleri. MEB yayınları.
23. OECD (The Organization for Economic Cooperation and Development). (2012). Connected minds: Technology and today's learners, educational research and innovation. OECD Publishing. 29

24. Pedro, F. (2006). The new millennium learners: Challenging our views on ICT and learning. 25 Nisan 2019 tarihinde http://www.oecd.org/education/ceri/38358359.pdf adresinden edinilmiştir.

25. Sanders, W. L. ve Rivers, J. C. (1996). Cumulative and residual effects of teachers on future student academic achievement.

26. Şahin, M. C. (2010). Eğitim fakültesi öğrencilerinin yeni binyılın öğrencileri (OECD-New millenium learners) ölçütlerine göre değerlendirilmesi. Yayınlamamış doktora tezi, Anadolu Üniversitesi Eğitim Bilimleri Enstitüsü, Eskişehir.

27. Şimşek, Ö., Demir, S., Bağçeci, B. ve Kinay, İ. (2013). Öğretim elemanlarının teknopedagojik eğitim yeterliliklerinin çeşitli değişkenler açısından incelenmesi. Ege Eğitim Dergisi, 14(1), 1-23.

28. Tabachnick, B. G. And Fidell, L. S. (2013). Using multivariate statistics. Boston, Pearson

29. Thomas, K. S. (2014). The effectiveness of select upward bound programs in meeting the needs of 21st century learners in preparation for college readiness. Yayınlanmamış doktora tezi. Department of Educational Leadership, Atlanta. Georgia.

30. Trilling, B. ve Fadel, C. (2009). 21st century skills: Learning for life in our times: learning for life in our times. John Wiley \& Sons.

31. Türk Sanayicileri İşadamları Derneği (TÜSİAD). (2012). 21. Yüzyıl Becerileri ve Eğitimin Niteliği Toplantı Dizisi. 26 Haziran, Sabanc1 Center, İstanbul.26.04.2019 tarihinde https://tusiad.org/tr/component/k2/item/5700-tusiad-21yuzyil-becerileri-ve-egitimin-niteligi-konulu-toplantidizisinin-ilkini-gerceklestirdi adresinden edinilmiştir.

32. Wagner, T. (2008). The global achievement gap: Why even our best schools don't teach the new survival skills our children need-and what we can do about it. Basic Books.AASL standartları.

33. Williams, C., Gannon, S. ve Sawyer, W. (2013). A genealogy of the 'future': Antipodean trajectories and travels of the '21st century learner'. Journal of Education Policy, 28(6), 792-806.

34. Woods-Groves, S. (2015). The human behavior rating scalebrief: A tool to measure 21st century skills of K-12 learners. Psychological Reports: Measure \& Statistics, 116(3), 769-796.

35. Yangın, B. (2005). İlköğretim Türkçe Dersi Öğretim Programı ve Kılavuzunun Değerlendirilmesi. Kuram ve Uygulamada Eğitim Bilimleri, 5 (2), 477-516.

36. Young, J. S. (2012). Linking learning: Connecting traditional and media literacies in 21st century learning. Journal of Media Literacy Education, 4(1), 70-81. 